\title{
Democratic Deviations and Constitutional Changes: The Case of Turkey ${ }^{1}$
}

\section{Lucia Picarella}

Universidad Católica de Colombia

\author{
Doi: 10.2478/ajis-2018-0041
}

\begin{abstract}
This article shows through a descriptive-qualitative methodology as the recent Turkish constitutional reform is fully inserted in the context of the strong debate on the transformations of contemporary democracies. In particular, the analysis emphasizes the underlying danger of this constitutional change, because the established super-presidentialism drives a strong drift away from the consolidation / institutionalization of democracy. Our conclusions show the risk of authoritarian involution from the total centralization of powers in the hands of the leader, which will have consequences both internally, an area in which there will be a stronger radicalization, and at the supranational level, because the heavy rerouting freezes the integrationist dreams.
\end{abstract}

Keyword: Turkey, constitutional reform, democratic involution

\section{Introduction}

Traditionally, Turkey has emerged as a case of singular interest, because if on the one hand the policies of westernization have favored a strong approach to the European Union, prospecting the interesting possibility of integration of a single country of Muslim majority, on the other hand the role that historically had the Islamic religion in shaping the Turkish socio-political arena, and, many times, their consolidation in the political-institutional space, strongly focus the discussion on the secular question of the separation of religion and politics (Bardakoğlu, 2006; Messner, 2000).

Undoubtedly, the drawing of the historical-constitutional frame of reference, supported by a qualitative-descriptive research methodology, underlines the singular contradiction of this territory, oscillating between secularism, democracy, nationalism, Islamic ideologies.

So, a stranger mix from which the underlying antithesis derives from Turkish political action, namely, the ambition to become the democratic archetype for the Islamic world - setting up an institutional prototype perfectly capable of reconciling the different nuances that shape this political system - and, at the same time, the deviations from the initial dreams, which stop the strengthening of democracy.

In this sense, the result of the April 2017 referendum, approving the constitutional change, that is, de facto, a super-presidentialism, determines a sudden involution that, inevitably, distances the two shores of the Mediterranean.

\footnotetext{
${ }^{1}$ This article is the result of a research project developed with the Aldo Moro Group of the International Masters in Political Science of the Catholic University of Colombia in agreement with the Università degli Studi di Salerno.
} 


\section{The Frame of Reference: A Panoramic}

Understanding the paradoxes and singularities that characterize Turkish territory cannot escape a quick consideration of its political and institutional history, a basic prerequisite for a critical evaluation of the democratic involution towards which Turkey is heading. In term of a properly political-administrative sphere, as well as a historical-geopolitical context, this system has been characterized by a great melting pot of races, religions and culture, which is significantly represented by the coexistence between two institutions, namely the 'sandjak' (administrative provinces) y las millet (Religious communities with their own jurisdiction) (Öktem, 1999: 1160; Tedeschi, 2006: 11).

Under the inspiration of Renaissance and the French Revolution, the XIX century begins with the great opening by the decadent empire to a stage of modernization, culminating in the 'Tanzimat', widely criticized by the Young Ottomans, supporters of an Islamic-liberal mold state, condensed in the Ottoman Constitution of 1876, a text that broadly expressed the contradiction mentioned at the beginning of this reflection between evolution and tradition. A text which, however, presents a significant intrinsic value, because if it cannot be recognized as the symbol of the beginning of the Turkish constitutional monarchy, it was undoubtedly fundamental for the determination of the following historical pages (Özbudun, 2005: 20), because properly through the following constitutional changes, was pushed more and more towards a democratic structure ${ }^{3}$.

The events that characterized the European context in the late 1800s, in particular the upheavals in the Balkans and the Russo-Turkish war, effectively laid the foundations for the development of the clandestine movement of Young Turkish -focused on the need for renewal, and, mostly, to endow the political system with a modern constitution - and, indeed, properly their revolution, gave rise to the so-called Ottoman constitutional period (1908-1913), that is, a first experience of Parliamentary monarchy ${ }^{4}$, suddenly transformed into a military oligarchy due to the worsening of the international situation at the beginning of the $X X$ century. The unconditional capitulation after the defeat of World War I, marks the beginning of the profound Turkish political change, led by Mustafa Kemal, which led to the independence and conformation of the NationState (1919-1923). It seems appropriate to dwell on the events that characterized this phase, because the actions implemented represented, clearly, the basis of modern Turkish constitutionalism and, for the purposes of our analysis, a significant reading key.

In this sense, the starting point is represented by the Congress of Erzurum (1919), a consequence of the circular sent by Kemal to the governors of all the Anatolian provinces, in which the architect of the transformation - preoccupied by the hypothesis of a peace agreement that ignored the rights of the Turkish people - underlined the importance of convening a National Assembly, also making explicit reference to the sovereignty of the people.

In fact, the transition from theocracy to modernity crystallized in the meeting in Ankara of the

\footnotetext{
${ }^{2}$ The Tanzimat proclaimed relevant reforms in matters of equality, regardless of religion or race, in matters of taxation, justice, education (Dumont, 1989: 459).

${ }^{3}$ In fact, this text was inspired by the Constitution of Belgium of 1831 and the Prussian Constitution of 1850 , and presented all the characteristics of a constitutional text, specifying the sultanate as a form of state, Islam as state religion and Turkish as a language official. In addition, the text presented a list of citizens' rights, such as the right to education, security and private property, freedom of religion and the press, prohibition of torture and slavery. Also relevant was the creation of a legislative assembly partially elected by the people and formed by two chambers, through which was guaranteed the exercise of power. In spite of these developments, however, the Empire was still quite far from a true democratic constitution, because the Sultan continued to lead all decision-making dynamics, and, in addition, the absence of a true separation of powers and the creation of respective controls institutions did not allow the protection and application of the rights and freedoms listed (Özcan, 2012; Gözler, 2008).

${ }^{4}$ This stage was characterized by the reestablishment of the Constitution of 1876, suspended after the Turkish defeat in 1878, and by important constitutional changes (precisely, between 1909 and 1918, there were six constitutional changes) that favored the introduction of important rights, such as the right to assembly and strike, the freedom of the press (Vaner, 1988: 87).
} 
Great National Assembly (April 1920), a sui generis constituent organism that approved the enactment of the Kemalist Basic Law (1921), a provisional Constitution agreement that establishing organizational principles foreseeing the implementation of a new government ${ }^{5}$.

From this moment, starts a period of diarchy, that is to say, a coexistence between the nationalist government created by the Great National Assembly and the Sultanate, definitively abolished on the vigil of the Lausanne Peace Conference, whose treaty was ratified by the Second Grand National Assembly, which finally proclaimed the Republic of Turkey promulgating the new Constitutional Text (April 1924). The following constitutional amendments undoubtedly seemed to confirm the will to shape the state in conformity with western ideals, and in this sense, in application of Kemalist purposes, the constitutional reform of 1937 will constitutionalize the guidelines of the policy of the Turkish state (Article 2 ) $^{6}$. However, this is a text in which there are weaknesses, because the concentration of executive and legislative powers in the General Assembly, and the absence of control mechanisms to guarantee the application of the law and its constitutionality in matters of individual and collective rights, if theoretically betting on the materialization of a Rousseauian-style democracy, he expressed with the change of the party system all the risks of the involution of the majority democracy (Haykemez, 2003; Örmeci, 2012; Özbudun 2005: 21-22).

In fact, the beginning of the multi-party phase (1946) represents a significant line of demarcation both at the political and institutional levels.

The conquest of the majority by the Democratic Party (DP), a center-right party supported by Islamist movements that ended the republican (CHP) one-party period, drive to a new era characterized by a softening of secularism, condemnation of Islamic extremism and openness to capitalist policies.

In fact, the formation of a multi-party arena, required at the institutional level, the need to guarantee all the different expressions, a necessity which the Constitution - because of its faults clearly failed to protect, and therefore converged in the malaise expressed by intellectuals and students and that had as result the coup d'état of 1960 (Landau, 1974). With the aim of molding a new and more effective democratic system, based on a parliamentary and multi-party structure, was adopted a new Constitution (1961), considered as a great example of democracy. Obviously, founded this text the European Charter of Human Rights and the Universal Declaration of Human Rights (Aybay, 1977: 22; Isiksel, 2013), and it was legitimized by the modality of approval, namely, the vote of all those entitled (Özcan, 2012: 63-66; Tanör, 2007), in addition to the proclamation of Turkey as a Republic based on human rights (Article 2) and an extensive list of rights inspired by the principles of plurality (Özbudun, 2005: 23; Özcan, 2012: 66). However, again, in a short time the landscape was destined to change. The decade of the 70 s was characterized by violence, terrorism, by strengthening the power of the military, because the National Security Council, an independent judicial organism, often began to centralize the power.

Correspondingly, at the political level, there is a strengthening of political Islamism, represented by Erbakan's National Order Party (NOP), re-founded in the National Salvation Party (NSP) and which gained power in a coalition with the Republicans in 1973.

\footnotetext{
${ }^{5}$ In fact, it is a provisional text, which cannot be read as a republican constitution, because does not have republican rights or provisions. It is important to point out, in the perspective of this reflection, again the contrast between conservative positions, expressed in the principle according to legislative decisions must conform to Sharia, and modernization, because the foresight of the new government was based on the principle that the sovereignty resides in the nation.

${ }^{6}$ Quickly, according to this constitutional change, the state government must be inspired by the republican principle, nationalism, the populist principle - aimed at underscoring the national sovereignty as the foundation of the Republic -, statehood - through which make easy the return to the state of the economic and commercial activities concentrated in foreign hands-, the evolutionary principle - which, despite terminological issues, showed the fidelity to the Ataturk revolution and the obligation to perfect it by means of legal tools for the purpose of avoiding subversion - , and, finally, secularism. A principle which causes a few difficulties and which again verified the contradictions of the adoption, at formal level, of a properly Western principle in an Islamic Country, in clear contrast with what practice showed, namely, the validity of Alcoranics formulas. Particularly in reference to the difficulties of terminology related to these principles, see Melis (2012).
} 
From this moment, through the equalization between the Islamic schools (imam-hatip) and the state schools, the political scene was occupied by the powerful Islamism lobby group, to which Erdogan belong. Also, in consideration of the institutional sphere, the Constitution was totally emptied of its democratic meaning, with the modification of art. 11 which, by overturning the initial forecasts, established the contraction of fundamental freedoms and rights for the purposes of protecting national integrity.

In this context, which also included economic problems and undoubtedly the absence of an internalization of democratic culture, explode a new coup in 1980, which predictably adopted by a new Constitution (1982), that was defined as an "anti-constitution" for the violations of the human rights present in it (Isiksel, 2013: 720); a text that, until the April 2017 referendum, has guided the Turkish state.

Also, the priority of this text seems to be the concentration of power, particularly in the hands of the executive under the control of the National Security Council. And, for this purpose, the action of restyling perpetrated was impressive, because, for example, in art. 2 the word founded was replaced by respect for human rights (Özcan, 2012: 66-68), likewise the art. 13 properly titled "restrictions of rights and freedoms" in cases of threats to national sovereignty, integrity of the state, public order and morality, and, on this route, it moved the creation of institutions to control the university autonomy, the press, the freedom of association (Biagini, 2002: 148).

Too, the political climate was very complicated, because if the Islamist parties were officially disqualified, the government itself favored Islamism, in particular the diffusion of Islamic education, to confront religious extremism and communism (Narli, 1996; Karmon, 1997), until achieved in the election of 1996 the conquest of the Presidency of the Republic by the WP (Welfare Party) of Erbakan, convinced to transform Islam into the tool capable of facing both capitalism and communism ${ }^{7}$.

The end of the 1990s, then, will present a paradoxical situation, oscillating between the resurrection / radicalization of political Islam and the impulses towards necessary constitutional changes, prerequisites for a membership to the EU.

\section{The Democratic Contraction: From Parliamentarism to Hyper-Presidentialism}

Undoubtedly, a new paragraph in the Turkish political-constitutional history opens with the official candidacy to join the European Union (1999), a time when starts more substantial efforts at constitutional reforms for to comply with the Copenhagen criteria ${ }^{8}$.

However, in spite of a greater openness in the delicate area of fundamental rights, which clearly represents the terrain of confrontation with the EU, the efforts failed to solve the problems of democratize and, then, failed to overcome the obstacles that stopped the integrationist dreams. In fact, the elimination of state monopoly over the media, the possibility for public employees to be members of political parties and associations - although it remained impossible for them to strike and the strengthening of the Constitutional Court, represented a few steps, on which floated the weight of the absence of a true separation of powers, of parliamentary immunity, of the strong powers of political leaders, of the death penalty, abolished only in 2004.

So, as earlier mentioned, the attempts to rise to a true "western" democracy, clashed with the

\footnotetext{
${ }^{7}$ The WP was born in 1983, after the disqualification of the NSP, and its electoral base was formed mainly by rural migrants and religious conservatives, and, geographically, the fort was represented by the cities of the interior. In spite of his secular education, Erbakan joined the religious movements, and developed his ideology founded, first, on the strong criticism of Turkish politics, accused of supporting imperialism and Zionism while, owners of the largest American banks, conspired against the whole world. From there, in the second place, it develops the vision of Islam as a mechanism to create a just order, whose values were not opposed to modernity. In this sense, for example, MUSIAD was founded, an independent association of industrialists and entrepreneurs, which represented the core of the Islamic economic system (Shankland, 1999; Vaner, 2000; Noyon, 2004).

${ }^{8}$ For these criteria: http://ec.europa.eu/enlargement/policy/glossary/terms/accession-criteria_en.htm.
} 
contradictions that continued to characterize the Turkish political system, mostly identified in a significant exacerbation of political Islamism, which seemed to end in 1997, with Erbakan's ineligibility and the consequent disappearance of the WP, accused of violating the principle of state secularism ${ }^{9}$. The global scene that emerged after $9 / 11$, and the consequent chess games that were set in motion to fight the global threat, namely, Islamic terrorism, evidently placed Turkey in the eye of the storm. The image of compatibility between moderate Islamism and a secular and democratic republic was faced with the internal growth of anti-American / anti-Western positions and the risk of more radical Islamist forces, a danger that seemed to materialize with the attacks of 2003 in Istanbul, claimed by Al Qaeda (Erginsoy, 2001). It was precisely in this complicated context that fine-tuned the strategies for the detonation of a new leadership, Tayyip Erdogan, that from the outset showed his willingness to lead and transcend Turkish political change and modernization. Away from the conservative currents, faithful to the erbakanianas positions, and rehabilitated to the political life, founded in 2001 its party, AKP (Party of Justice and Development), that appeared like moderate, secular, pro-European. The majority in the 2002 elections, conquered through the capacity to gain support from both the secular and religious sectors, was the basis on which to support Erdogan's ambitious program, which, on the internal level, declared his favor of necessity to separate religion and politics, to promote a multi-party system and to respect human rights, to stabilize the economy.

On the foreign policy, Erdogan to approach to Western positions, declaring his unconditional support for the war on terrorism, his willingness to join the EU, the consolidation of political and economic relations with the Arab world (Rubin, 2005). An agenda that clearly had to start with the constitutional change, one of the cardinal goals of the AKP and its leader, and which aroused from the outset doubts about the possibility to implement a change really in accordance with democratic parameters. In fact, the paradoxes underlying this political system soon became apparent, so much so that the Constitutional Court raised the constitutionality of proposals presented by the AKP ${ }^{10}$, and, too, the rapprochement with Islamist positions, confirmed the perplexities of the EU, which rejected the integration, a decision that obstructed relations between the Union and Turkey ${ }^{11}$.

The evolution of recent years confirms the drift that has taken place, corroborating the position of those who saw in a new constitutional change the risk of establishing an authoritarian system based on a single party. In this sense, we can see the constant deterioration of the role of the military, historically depositaries of secularism and the protection of democracy, and, of course, the measures that came after the attempt coup of July 2016, justified by the insurgent military as a necessary action for the restoration of a democratic order. A project that failed in convulsive hours, enough to trigger bloody confrontations between counterparts, as well as Erdogan's cruel reaction which invited the Country to resist the coup, taking to the streets -, and finally the concern of the whole world, with the eyes of Russia and United States focused on the possible consequences of these events. Consequently, and despite the proclamations of world leaders to respect the democratic order, the intransigent counterattack of the President was not long in coming and, in a State in total chaos, began the bloodbath.

Events that, as mentioned, will undoubtedly affect Turkey's international relations, projecting new possible global scenarios. Quickly regaining power and reestablishing his control, Erdogan declared as an enemy of Turkey any country that provide protection to the radical Islamist

\footnotetext{
${ }^{9}$ It should be noted, for example, the radicalization of Erbakan's position when, in a provocative way, affirmed the need to fight corruption with the restoration of Sharia; as well as its opposition to the strengthening of tools for the protection of women from domestic violence (Ustun, 1998; Narli, 1999).

${ }^{10}$ In fact, the separation between religion and politics was not achieved, and very strong were the debates concerning the prohibition or less of the veil, as well as with reference to the definition of adultery as a criminal offense, and the reform in 2012 of the instruction, that continues to strengthen the Koranic institutes.

${ }^{11}$ Negotiations began in December 2004 and were clearly fueled by strong debates that highlighting noncompliance with Copenhagen parameters, as well as the importance of solving problems in relations with Greece and, mostly, a lifestyle and a different culture of European identity. Positions supported by the majority of the European population which disillusioned the Turkish population, strengthened anti-European sentiments by claiming the Islamic character of their country. To deepen: Pan (2005).
} 
ideologue Fetullah Gulen, in exile in the USA who, in turn, maintained its position of rejecting the Turkish request for extradition ${ }^{12}$. The hardening of the tone of the Turkish leader seemed then a clear warning to the American government, because, assuming that the Turkish armed forces are the second largest permanent forces in NATO and, together with Israel, the strongest power in the Near East, the Turkish government suspended its international commitments of military reciprocity ${ }^{13}$.

The flow of the consequent implications was quickly formed in the minds of international relations experts, because the distension in the diplomatic-energy relations with Moscow if on the one hand stop the Western strategies of containment of Russia, with the consequent reflections on energy supply to Europe, on the other hand this improvement did not necessarily imply a limitation of Turkish imperialist policies in the Middle East - territory that containing the US breathing - and, mostly, to end their ambiguous relations with fundamentalist groups fighting against Damascus.

In addition, the growing consideration of restoring the death penalty - now not only as a measure to punish the insurgents - would mean completely cutting off ties with Europe and, also, with NATO, because both are based on respect for Democratic principles. Undoubtedly, front of the crossing of strengthening democratic consolidation as an antidote to deviations and, conversely, taking advantage of the situation to centralize all power in their hands, the Turkish leader has definitely chosen the latter option, deeply deteriorating - in a political level - the precarious balance between powers. Well, what emerged in the post-coup has been an immediate turn towards the worst populist face, as likewise toward the strengthening of Islamic radicalization and the dismantling of the secular / moderate structure, an action confirmed by violent cleansing in all political, administrative, judicial, academic and military units. The declaration of the state of emergency, and its governance, has very simply fueled and accelerated the authoritarian drift, precipitating in the final test, namely the approval of the constitutional reform, necessarily submitted to a referendum due to the lack of achievement of the quorum necessary to avoid a popular consultation $^{14}$.

As predictable, the election campaign has been polarized between Erdogan's position, which aimed at strengthening the nationalist electorate, has called for a vote for "a Homeland," while the oppositions called for a no "for freedom and democracy". Moreover, this campaign was characterized by episodes of intimidation, artifices and illegalities, summarized in the removal of OSCE international observers, in the pre-eminent presence of Erdogan in the media and in the meeting on both sides of the Bosporus, in acts of violence against activists and in the arrests of members of the pro-Kurdish party (HDP), in the reduction and limitation of political freedoms - such as the elimination of sanctions for violations of par condicio - in the name of the state of emergency. A violations of democratic standards repeatedly evidenced by international experts who have demonstrated the lack of impartiality and freedom in voting operations, also challenging the regularity of the consultation, due to the use of a large number of ballots without official seal -, and which have led to the cancellation of the Turkish Ministers' meetings in some European countries $^{15}$. Together with this reflection, it is interesting an examination of the vote ${ }^{16}$ and its

\footnotetext{
${ }^{12}$ Erdogan accused Gulen of having organized the coup, despite his condemnation of this event. The preacher, former ally of the Turkish leader long since converted into a strong enemy, has been in voluntary exile in the United States since 1999, where - according to the news circulated after the accusations brought by Erdogan he was the administrator of an economic empire. Some rumors that fomented the hypotheses of an international conspiracy, clearly feed by the Erdogan.

${ }^{13}$ Specifically, it looked like an action directed properly at the US government, due to the decision to establish a no-fly zone in Turkish airspace and cut off the electricity from the Incirlik airbase - whose general was detained because he was accused of participating in the coup - they were guarded fighting aircraft of the USA and of the other members of the international anti-SIIL coalition.

${ }^{14}$ In particular, Erdogan conquered 339 favorable deputies over 550, remaining below the 367 votes necessary to approve the reform through institutional channels.

${ }^{15}$ Mostly, in France, Germany, Holland; an action that has triggered the resentment of the Turkish leader who has strongly criticized the "crusade" of foreign nations, also threatening a revision of the agreements on migrants and the restoration of the death penalty.
} 
geographic distribution, since, compared to expectations, Erdogan managed to overcome his opponents by a difference of only 2.6 percentage points (51.3\% vs. $48.7 \%)$.

A result that has to be combined with the significant loss of electoral support of the AKP-MHP bloc (-10.7 percentage points) compared to the 2015 elections, as well as the fracture between urban provinces (where wins the "not" to the reform) and rural contexts (where wins the "yes" to the reform) and, likewise, the withdrawal of the more educated AKP electorate, which supports the "not" to the reform.

The reading of this result, then, must be verged first at the internal-partisan level, because the absence of the expected popular consecration may favor a split in AKP, with the leader who could quickly get back in the head of this party, without waiting for the official publication of the constitutional reform and, likewise, advancing the general and presidential elections (formally set for November 3, 2019). Second, in consideration of the external level, the EU has reiterated the concern of a reform that gives to Erdogan unbridled powers, evidencing that the implementation of this constitutional package that would extend the presidency until 2034 and which eliminates any form of check and balance, will move to the suspension of negotiations for the Turkish membership to the EU.

Thus, although it has been a "contained" electoral victory, is setting up the change of the face of Turkey in an autocracy far from the ideals of Ataturk. Of course, the super-presidentialism that has been established with this reform, give to Erdogan an uncontainable power, because it realized a concentration in his person of all the political power, that is to say the leadership in his party, and institutional, namely to centralization in their hands of the three powers without any parliamentary control, due to the total disempowerment of the Assembly ${ }^{17}$.

A condensation of lifetime, which, of course, is ramified in all sectors, as demonstrated by the operation of silencing - prolonged after the coup - of opposition and media power.

\section{Conclusion}

Undoubtedly, wake a great apprehension the erosion of the rule of law and the involution of the democratic process that start up in Turkey with the approval of the constitutional reform and with the consequent change in the Presidential Republic.

If, historically, it has been a country characterized by the constant tension between unfulfilled promises and ambitions, by the mixture between ethnic and religious matrix, by the ideals of secularism and democracy, however, now it is presented in the world context a profoundly different Turkey. Well, a change that, in the immediate future, will give us consequences both in terms of integration, evidencing the failure of integrationist impulses and dreams that, today, crash against the fortification of nationalist schemes. So too, in terms of extremism and radicalization, because the implications of this transformation will spill over all ethnic-religious minorities and opponents of the new order.

The drift towards which Turkish democracy is headed, is also condensed in the submission of the rules of the democratic game to the "one-man rule", and, necessarily, the corollaries coming

${ }^{16}$ The percentages of official votes have been consulted in European Union website, http://europa.eu/

17 More specifically, the constitutional reform provides for the abolition of the government and the Prime Minister, because the executive power is submitted to the President of the Republic, elected every five years in conjunction with the political elections, which therefore acquires all powers of the prime minister, together with the power to appoint and revoke the ministers and to sign executive decrees. In fact, along with the elimination of the balance of power - typically based on a parliamentary system on the motion of confidence-, this reform also eliminates the principle of impartiality, i.e. the possibility of the President of the Republic being a member I leader of a political party: in this case, what is abolished is the obligation for the President to resign from any position once elected. In addition, the reform introduces new provisions with reference to the composition of the Judicial Council and Public Ministries, among the most important organs of the Turkish Republic, because the number of members falls from 22 to 13, of which 6 shall be appointed by the President and 7 by the Parliament. The debates that preceded the approval of this reform were very broad, to deepen: Isiksel (2013: 724); Koker (2013); Mahçupyan - Uçum - Genç (2013). 
from this election will soon arrive: the future of democracy is hanging in a thread, and in Turkey the risk of impact takes chilling profiles.

\section{References}

Aybay, R. 1977. Some contemporary constitutional problems in Turkey. British Society for Middle Eastern Studies. Bulletin, 4(1).

Bardakoğlu, A. 2006. Religion and society: new perspevtives from Turkey. Ankara: Presidency of Religious Affairs.

Biagini, A. 2002. Storia della Turchia contemporanea. Milano: Bompiani.

Dumont, V. P. 1989. "La période des «Tanzimat» (1839-1878)". Histoire de l'Empire ottoman, ed. R. Mantran, Paris: Fayard.

Erginsoy, A. 2001. "Turkey Confronts Challenge of Maintaining Secular State Model". Eurasianet, september.

Gözler, K. 2008. Anayasa hukukuna giriş. 2a ed. Bursa: Ekin Kitabevi.

Hakyemez, Y. 2003. Türk Anayasalarında Çoğunlukçu Demokrasi Anlayışı. Ankara: Üniversitesi Dergiler Veritabanı.

Isiksel, T. 2013. "Between text and context: Turkey's tradition of authoritarian constitutionalism". International Journal of Constitutional Law, 11(3).

Karmon, E. 1997. "Radical Islamic Political Groups in Turkey". MERIA Journal, vol. 1 n. 4.

Kpker, L. 2013. Making of a New Constitution in Turkey Monitoring Report: The Basic Principles and the Choice of Government System in the New Constitution. Turkey: Sezen Ünlüönen.

Landau, J. 1974. Radical politics in modern Turkey. Leiden: Brill.

Mahçupyan, E. - Mehmet, U. - Genç, O. 2013. Making of a New Constitution in Turkey Monitoring Report: What sort of a constitution are we heading towards? TESEV: Democratization Program

Melis, N. 2012. "Il linguaggio politico della repubblica turca: la costituzione del 1924 come caso di studio". Lingue, letterature, nazioni. Centri e periferie tra Europa e Mediterraneo, ed. Mazzon G. \& Putzu I. Milano: Franco Angeli.

Messner, F. 2000. "Les relations État-religions dans les pays membres de I'Union européenne". AA.VV., Religions, droit et sociétés dans l'Europe communautaire, Paris: PUAM.

Narli, N. 1996. Moderate Against radical Islamicism in Turkey. Essen: Essen University.

Narli, N. 1999. "The Rise of the Islamist movement in Turkey". MERIA Journal, vol. 3, n. 3.

Noyon, J. 2004. Islam, politics and pluralism: theory and practice in Turkey, Jordan, Tunisia and Algeria. Londres: The Royal Institute of International Affairs.

Öktem, E. 1999. "La Cour constitutionnelle turque définit le nationalisme, principe de la République". Revue droit publique et de la science politique en France et a l'etranger. n. 4.

Örmeci, O. 2012. Turkish Constitutions in Comparative Perspective (1921, 1924, 1961, 1982).Uluslararası Politika Akademisi. http://politikaakademisi.org/turkish-constitutions-1921-1924-1961-1982-incomparativeperspective/

Özbudun, E. 2005. "Constitutional law". Introduction to Turkish law, ed. Ansay T. \& Wallace D., The Hague: Kluwer Law International.

Özcan, A. 2012. Mukayeseli Anayasal Denge ve Denetleme ve Türkiye. Istanbul: The German Marshall Fund of the United States in Collaboration with the ARI Movement and the Black Sea Trust for Regional Cooperation.

Pan, E. 2005 (july). "Europe: integrating Islam". Council on Foreign Relations.

Rubin, M. 2005. "Freid in Turkey". National Review Online, august.

Shankland, David. 1999. Political Islam: the rise of Erbakan, en Islam and Society in Turkey. Huntington: The Eothen Press.

Tanör, B. 2007. Osmanlı- ürk anayasal gelişmeleri. Istanbul: Yapı Kredi Yayınları.

Tedeschi, M. 2006. "La comunità come concetto giuridico". Comunità e soggettività, ed. M. Tedeschi, Cosenza: Pellegrini Editore.

Ustun, R. 1998. "Freedom under Wraps: Islamic Garb on Turkish Campuses". MERIA Journal, vol. 2, n. 3.

Vaner, S. 1988. "État, société et partis politiques en Turquie depuis 1902". Revue des mondes musulmans et de la Méditerranée, 50 (1).

Vaner, S. 2000. "La stabilité de la Turquie a l'épreve de l'éthnicité de l'Islam politique". UNISCI DISCUSSION PAPER, Madrid, n. 16. 